\title{
Update on the development of a novel dry cow therapy using a bismuth-based intramammary teat seal in combination with the bacteriocin lacticin 3147
}

\author{
Fiona Crispie $^{1,2}$, James Flynn ${ }^{2}$, R. Paul Ross ${ }^{1,3}$, Colin Hill ${ }^{3,4}$ and William J. Meaney ${ }^{2}$ \\ ${ }^{1}$ Teagasc, Dairy Products Research Centre, Moorepark, Fermoy, Co Cork \\ ${ }^{2}$ Teagasc, Dairy Production Research Centre, Moorepark, Fermoy, Co Cork \\ ${ }^{3}$ Alimentary Pharmabiotic Centre, University College Cork \\ ${ }^{4}$ Department of Microbiology, University College Cork
}

Public concerns over the widespread prophylactic use of antibiotics have led to a search for alternatives to dry cow therapy for the prevention of intramammary infections. A popular alternative is to infuse a teat seal at drying-off. The teat seal is a viscous non-antibiotic formulation and when it is infused into the teat canal and the teat sinus it forms an internal seal that provides a physical barrier to invasion by mastitis-causing pathogens. Enhancement of teat seal formulations may be achieved using non-antibiotic additives such as bacteriocins, potent proteins produced by some bacteria that have the ability to kill other microorganisms. This paper traces the history of investigations at

Key words

Cow, Udder, Mastitis, Dry cow therapy, Teat seal, Lacticin. Moorepark Research Centre into the efficacy of teat seal plus lacticin 3147, a bacteriocin produced by Lactococcus lactis DPC3147, in the prevention of intramammary infections in dry cows. Indications from on-going investigations are that a dry cow formulation combining the two products has considerable potential as a non-antibiotic prophylactic product.

Irish Veterinary Journal

Volume 57: 652-656, 2004

\section{Introduction}

Mastitis causes significant economic losses to the dairy industry, with annual costs worldwide estimated at $\$ 35$ billion (Wellenberg et al., 2002). For over 50 years, the practice of treating all udder quarters with a long-acting antibiotic at drying-off (dry cow therapy, DCT) has been an important part of mastitis treatment and prevention on dairy farms. DCT has been hugely successful in curing many existing subclinical infections and also offers short-term protection against new intramammary infections (IMIs) during the early dry period. Public concerns over the widespread prophylactic use of antibiotics, coupled with an increasing interest in organic farming, have led to a search for alternatives to DCT for the prevention of intramammary infections.

Corresponding author

\section{W. J. Meaney}

Teagasc Dairy Production Research Centre

Moorepark, Fermoy, Co Cork

Republic of Ireland

Phone: +3532542285

Fax: +3532542340

E-mail: bmeaney@moorepark.teagasc.ie
The increased susceptibility of mammary gland to new IMIs during the early dry period is believed to be mainly due to delays in the formation of a complete keratin plug in the streak canal in the early dry period (Williamson et al., 1995). This can be overcome through the application of an internal teat seal at drying-off (reviewed in Crispie et al., 2004a).

Teat seal (Boviseal, Bimeda, Cross VetPharm Group Ltd., Dublin, Ireland) is a non-antibiotic intramammary dry cow product currently sold in many countries worldwide (Orbeseal, Pfizer Animal Health). It is a viscous formulation that, when infused into the teat canal and the teat sinus, provides a physical barrier to invasion by mastitis-causing pathogens. The formulation is primarily comprised of bismuth subnitrate (65\%) and liquid paraffin and is presented in a syringe for

\begin{tabular}{|ll|}
\hline \multicolumn{2}{|l|}{ Abbreviations } \\
AU & arbitrary units \\
CMT & California Mastitis Test \\
DCT & dry cow therapy \\
DWP & demineralised whey protein \\
IMI & intramammary infection \\
RAPD & random amplification of polymorphic DNA \\
SCC & somatic cell count \\
TYG-L & solubilised preparation of lacticin TYG \\
\hline
\end{tabular}


intramammary application. Infusion of teat seal without an antibiotic has been shown to be as effective as a long-acting antibiotic in preventing new intramammary infections during the dry period in cows which were infection-free and had somatic cell counts (SCC) of less than 200,000 ml-1 at dryingoff (Woolford et al., 1998; Berry and Hillerton, 2002; Huxley et al., 2002).

Enhancement of teat seal formulations may be achieved using non-antibiotic additives such as bacteriocins, potent proteins produced by some bacteria that have the ability to kill other microorganisms. The incorporation of a bacteriocin into the seal may provide a method to prevent inadvertent contamination during infusion, improving the safety of the product in the hands of the untrained user. Lacticin 3147 , a bacteriocin produced by Lactococcus lactis DPC3147, has received much attention in this regard. The purpose of this publication is to summarise the data available on the efficacy of the teat seal in combination with lacticin 3147 in the prevention of mastitis.

\section{Why bacteriocins?}

Bacteriocins were first proposed for treatment of mastitis when the results of trials carried out by Taylor et al. (1949) indicated that a single intramammary infusion of nisin, a bacteriocin discovered in 1928 (Rogers and Whittier, 1928), was effective in treating both streptococcal and staphylococcal infections. Interest in the use of nisin as a therapeutic agent was renewed when Broadbent et al. (1989) showed that nisin was inhibitory to several Gram-positive, mastitis-causing pathogens. When nisin, in combination with lysostaphin, was administered by intramammary infusion, promising results were obtained with cure rates of 66\% for Staphylococcus aureus, 95\% for Streptococcus agalactiae, and $100 \%$ for Streptococcus uberis (Sears et al., 1992a,b).

Lacticin is a bacteriocin produced by L. lactis DPC3147 (Rea and Cogan, 1994; Ryan et al., 1998) that has a broad-spectrum of activity against all Gram-positive bacteria, including many mastitis-causing pathogens. The structure and mode of action of lacticin has been documented (McAuliffe et al., 1998, 2000; Martin et al., 2004). Ryan et al. (1998) examined the in vitro sensitivity of 24 mastitic streptococcal and staphylococcal isolates to lacticin 3147: all were inhibited, with the size of zones of inhibition varying from $\sim 10 \mathrm{~mm}$ to $17 \mathrm{~mm}$ (Ryan et al., 1998). The bacteriocin appeared to be more potent against streptococci than against staphylococci, with Streptococcus dysgalactiae $M$ the most sensitive strain tested. This was not unexpected, as intramammary infections caused by $S$. aureus have proved most difficult to cure with antibiotics, with the cure rates reported as low as 25\% (Pyörälä, 2002). L. lactis DPC3147 has been shown to inhibit representatives of the three main RAPD-type staphylococcal isolates found in a study of Irish farms (Fitzgerald et al., 1997; Twomey et al., 2000).

\section{Efficacy of teat seal plus lacticin in the control of streptococci}

In an in vitro study, 35 seals containing lacticin were tested for antimicrobial activity against Strep. dysgalactiae M: all 35 seals displayed effective antimicrobial action against this pathogen (Ryan et al., 1998, 1999).

The seal plus lacticin combination was infused into udder quarters (Ryan et al., 1999) in order to assess the effects on udder tissues. Clinical abnormality was not evident in any of the treated quarters observed at milking twice each day over the next five days. Overall, SCC trends were similar in the quarters infused with either the seal alone or with the seal plus lacticin.

The in vivo efficacy of teat seal plus lacticin against Strep. dysgalactiae $\mathrm{M}$ was assessed in dry cows (Ryan et al., 1999). For this purpose, 68 uninfected udder quarters were selected in 18 cows. After the last milking of the lactation, 33 quarters were infused with seal and 35 with seal plus lacticin. Three days after infusion, each of the 68 treated quarters was inoculated with 1.5 x $10^{4}$ cfu Strep. dysgalactiae M. The cows were observed twice daily (morning and evening) for clinical signs of mastitis. On the last day of the experiment (eight days after inoculation), samples of secretion were collected for microbiological analyses (Ryan et al., 1999). The challenge organism caused clinical mastitis in 14 sealed quarters, in $12(86 \%)$ of them by day two following the bacterial challenge, and in two quarters infused with seal plus lacticin, the first of which occurred on day 4 (Table 1). Thus, there were significant differences both in the rate of new infection $(\mathrm{P}<0.001)$ and in the intervals to each clinical event $(\mathrm{P}<0.001)$.

When all remaining non-clinical quarters were sampled at the end of the experiment, the challenge strain was recovered from a further six quarters that had been infused with seal alone but not from any of the non-clinical quarters that had been infused with seal plus lacticin. Combining these results with the clinical data, 20 sealed quarters and two quarters treated with seal plus lacticin were either clinical or shedding the challenge strain during the experiment (Table 1). Again, this difference was significant $(\mathrm{P}<0.001)$. In total, seal plus lacticin protected 33 (94\%) of the 35 teats against infection by the challenge inoculum of Strep. dysgalactiae M (Ryan et al., 1999).

TABLE I: Results of challenge with Streptococcus dysgalactiae M ( $\left.1.5 \times 10^{4} \mathrm{cfu}\right)$ in udder quarters treated with either teat seal or teat seal plus lacticin

$\begin{array}{lcccc}\text { Treatment } & \text { Quarters(n) } & \text { Clinical infections } & \begin{array}{c}\text { Strep. dysgalactiae M recovered from } \\ \text { non-clinical quarters (day 8) }\end{array} & \text { Total infections } \\ \text { Teat seal } & 33 & 14(42.4 \%) & 6 & 20(60.6 \%) \\ \text { Teat seal plus lacticin } & 35 & 2(5.7 \%) & 0 & 2(5.7 \%)\end{array}$




\section{Efficacy of teat seal plus lacticin in the control of Staphylococcus aureus}

The in vivo efficacy of teat seal plus lacticin against $S$. aureus was assessed in lactating cows (Twomey et al., 2000). After the morning milking, two quarters in each cow were infused with teat seal plus lacticin ( $4 \mathrm{~g}$; treatment group), and the two remaining quarters in each cow were used as unsealed controls. Two hours later the unsealed control quarters and the quarters treated with seal plus lacticin were all inoculated with a challenge inoculum of $S$. aureus DPC5246. The number of bacteria in the challenge inoculum was altered in two experiments. When a deliberate challenge with $\sim 1.7 \times 10^{3} \mathrm{cfu}$ of $S$. aureus DPC5246 per quarter was used, a concentration of $\sim 33,000 \mathrm{AU}$ lacticin per seal caused a significant reduction $(\mathrm{P}<0.001)$ in the numbers of quarters shedding $S$. aureus DPC5246. The $S$. aureus challenge survived in 19 (66\%) of the 29 control quarters and in four (14\%) of the 29 quarters infused with teat seal plus lacticin (Table 2). In addition, the presence of teat seal plus lacticin also resulted in a reduction in the total number of viable $S$. aureus DPC5246 cells recovered. When a higher challenge inoculum level of $\sim 6.8 \times 10^{3}$ cfu per quarter was used, the teat seal plus lacticin formulation $(33,000 \mathrm{AU} / \mathrm{seal})$ was less successful in reducing the number of quarters shedding $S$. aureus (Table 2).

While teat seals are not designed for the treatment of mastitis in lactating cows, the data obtained in this trial demonstrated that teat seal plus lacticin reduced both the number of quarters shedding $S$. aureus and the numbers of bacteria shed. It was speculated that if a similar formulation was developed as a dry cow product, it should reduce the risk of mastitis considerably (Twomey et al., 2000).

\section{Development of a milk-based lacticin formulation}

The production of lacticin using a variety of food-based media for the growth of L. lactis DPC 3147 has been reported (Morgan et al., 1999). Of the culture media evaluated, a $10 \%$ reconstituted demineralised whey protein (DWP) was considered the most suitable both in terms of the economics of production and of culture performance. This substrate was used to produce a lacticin-powder suitable for blending with teat seal. Lacticin was concentrated from the clarified DWP fermentate,

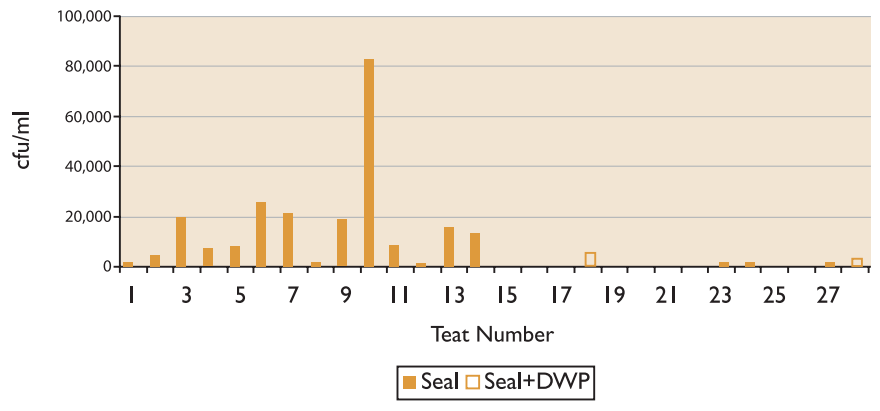

FIGURE I: Recovery of Staphylococcus aureus DPC5246 from milk I8 hours after experimental infection ( I,340 cfu) of udder quarters previously infused with either teat seal or teat seal plus DWP powder (from Crispie et al., 2004b).

freeze-dried and milled (Crispie et al., 2004b). A highly active powder (lacticin DWP) containing $\sim 1.6 \times 10^{6} \mathrm{AU} \mathrm{g}^{-1}$ was produced and blended with teat seal $(0.1 \mathrm{~g}$ of powder per $4 \mathrm{~g}$ of teat seal). The teat seal plus lacticin DWP formulation was filled into intra-mammary syringes and sterilised by irradiation. The effectiveness of this formulation in protecting against mastitis pathogens in vivo was investigated.

The teat seal plus lacticin DWP formulation was compared with commercial teat seal in an experiment using 28 quarters in seven cows selected on the basis of their udder health. Udder quarters were randomised and two quarters in each cow were infused with teat seal, while the remaining two quarters were infused with teat seal plus lacticin DWP. Two hours later, an inoculum of 1,340 cfu viable $S$. aureus DPC5246 was infused, via the streak canal, into each of the 28 quarters; $18 \mathrm{~h}$ later, the teat seals were removed, foremilk samples were taken in an aseptic manner and bacteria were enumerated (Figure 1). Significantly fewer viable $S$. aureus DPC5246 cells were recovered from quarters that had been infused with teat seal containing the lacticin DWP than from quarters infused with commercial teat seal $(\mathrm{P}<0.001)$.

\section{Tissue tolerance studies}

Three different experiments were performed to assess tissue tolerance to the various lacticin 3147 preparations blended with

TABLE 2: The effectiveness of teat seal plus lacticin (32,768AU/4g teat seal) in eliminating Staphylococcus aureus DPC5246 from artificially infected udder quarters of lactating cows compared with untreated controls. Shedding was evaluated $18 \mathrm{~h}$ after inoculation of $S$. aureus

\section{Treatment}

Untreated

Teat seal + lacticin

Untreated

Teat seal + lacticin

${ }^{a, b}$ Values with different superscripts within an experiment are significant $\mathrm{P}<0.001$.
Quarters inoculated (n)

29

29

20

20
Quarters shedding S. aureus

$19(66 \%)^{\mathrm{a}}$

$4(14 \%)^{b}$

$16(80 \%)$

$11(55 \%)$ 
teat seal. Teats of lactating cows whose foremilk was free of pathogens and had less than 200,000 SCC ml ${ }^{-1}$ over three consecutive milkings were selected for the three studies. Approximately $8 \mathrm{~h}$ after treatment, seals were removed and milk samples were collected. Udder quarters were sampled for the next ten consecutive milkings. Before and after infusion of the test formulation, the SCC status was assessed by flow cytometry using a Somacount 300 Somatic Cell Counter ${ }^{\circledR}$ (Bentley Instruments Inc., USA). To overcome the problem of seal particles interfering with the operation of the automatic somatic cell counter, the California Mastitis Test (CMT) was used as a subjective measure of SCC for the first three samplings after infusion. CMT readings were scored on a scale of 1 to 5 . However, when plotting the mean CMT, the presence of clots was also taken into consideration. Milk clots were scored on a scale of 1 to 4 and this value was added to the CMT score (i.e., a sample with a CMT reading of 5 and a clot score of 2 was given a final CMT reading of 7 ).

Five cows were used in the first experiment. In each cow individual udder quarters were treated with seal only, with seal plus lacticin DWP, with a commercial antibiotic preparation containing sodium cloxacillin (Orbenin QR, Pfizer Animal Health, Ireland), or were left untreated. Quarters infused with teat seal containing the lacticin DWP had higher somatic cell counts than the untreated quarters or quarters infused with teat seal alone. However, when the mean $\log$ SCC data from the four samples pre-infusion and the final two samples postinfusion were compared between treatments the differences were not significant $(\mathrm{P}=0.352)$. Additionally, when the mean $\log$ SCC post-infusion were compared, the differences between the treatments were insignificant $(\mathrm{P}=0.078)$.

For the second experiment lacticin was prepared from a synthetic medium TYG (lacticin TYG) in a similar manner to the DWP powder, and was blended with teat seal. In this experiment, individual udder quarters of five cows were treated with seal, with seal plus lacticin DWP, with seal plus lacticin TYG, or were left untreated. Quarters infused with seal plus lacticin DWP or with lacticin TYG had elevated SCC values in comparison with the controls, but there were no significant differences between treatments in the mean log SCC postinfusion $(\mathrm{P}=0.111)$. When the mean $\log \mathrm{SCC}$ data from the four samples pre-infusion and the final two samples postinfusion were compared across treatments the differences were not significant $(\mathrm{P}=0.331)$.

In the third experiment, two quarters in each of eight cows were infused either with teat seal plus a solubilised preparation of lacticin TYG (Lacticin TYG-L) or with seal alone; one of the remaining quarters was designated as an untreated control, while the fourth quarter was disregarded. There was no evidence of irritation in any of the quarters regardless of treatment and there were no differences between SCC readings post-infusion $(\mathrm{P}=0.222)$. Also, there were no significant between-treatment differences in the mean SCC readings of the four samples pre-infusion and the final two samples postinfusion $(\mathrm{P}=0.244)$.

In general, in all three experiments, control teats that were either untreated or infused with commercial teat seal maintained normal readings and the mean CMT values for the first three milkings post-infusion were less than 1.5. Subsequent mean SCC values did not exceed $400,000 \mathrm{ml}^{-1}$ in any of the control samples. These data indicated that the teat seal was non-irritant, as reflected by similar cellular responses in the treated quarters and in the untreated quarters. SCC and CMT values for the quarters infused with sodium cloxacillin were similar to those of the untreated quarters.

Taken together, these results indicate that while the infusion of seal containing either the lacticin product or TYG-derived lacticin powders caused a rise in SCC, this effect was temporary and without any long-term negative effects on the cows. The solubilised lacticin preparation derived from TYG (TYG-L) did not cause irritation, suggesting that the irritation observed with teat seal containing lacticin powder derived from TYG or DWP may have been associated with the particulate nature of the powder preparations rather than with lacticin or some other substance from the processed fermentate. This finding is similar to those in some of the early in vivo mastitis studies with another bacteriocin, nisin (Taylor et al., 1949), in which relatively large particle sizes contributed to tissue irritation. The irritation was short-lived in all cases and, in fact, it may enhance the efficacy of teat seal plus lacticin by acting as an immunostimulant. Alternative substrates such as whey permeate are currently being evaluated for suitability for lacticin production.

\section{Overall perspectives: a dairy solution to a dairy problem?}

Although lacticin had been shown to be ineffective against Gram-negative bacteria (Rea and Cogan, 1994; Ryan et al., 1998), evidence that it is bactericidal to a broad range of Grampositive bacteria, including $S$. aureus, Strep. uberis and Strep. dysgalactiae, prompted investigations to determine whether or not a formulation containing lacticin plus teat seal would provide more efficient dry cow therapy.

Gram-positive bacteria, particularly $S$. aureus, cause major problems in mastitis control, particularly in herds where teat disinfection is rarely or never used and in autumn-calving herds, where the cows are at pasture at drying-off. The animal studies reviewed in this paper indicate that teat seal plus lacticin DWP provided good protection against colonisation of the udder by streptococci. While it did not achieve the same level of success against experimental infection with $S$. aureus, the results were promising; for instance, $18 \mathrm{~h}$ after infusion of a challenge dose of that pathogen into the teat ducts of lactating cows, there were fewer pathogens in milk from quarters that had been infused with seal plus lacticin DWP than in milk from those infused with seal only. Thus, the DWP-derived lacticin-enriched powder 
was capable of reducing the numbers of $S$. aureus being shed by the udder.

If the hygienic conditions are substandard and the technique of intramammary infusion at drying off is poor, the lacticin 3147 will not protect the udder from invasion by Gram-negative bacteria. However, in those circumstances, the short-lived rise in SCC induced by infusion of the teat seal plus lacticin DWP formulation might be beneficial, as a moderate stimulation of the immune system may enhance the innate defences of the udder to those microbes. It can be very difficult to assess the relative importance of an antimicrobial action versus the immune stimulatory effects of preparations that are irritants; in practice, the protective effect is probably a result of both activities. It remains a possibility that the irritant action of the infusate might exercise sufficient immunostimulatory effects to prevent Gramnegative bacteria from inducing mastitis in dry cows.

The current problems worldwide regarding antibiotic resistance and the debate regarding the prophylactic use of antibiotics in animals dictates that novel remedies and management practices are required to offset problems with bovine mastitis. The use of antibiotics for prophylactic purposes may be restricted in the future; for this reason, there is a growing need for effective natural alternatives. A non-antibiotic anti-mastitis dry cow formulation containing lacticin combined with an intramammary teat seal has considerable potential for the prevention of mastitis in dry cows.

\section{References}

Berry, E.A. and Hillerton, J.E. (2002). The effect of selective dry cow treatment on new intramammary infections. Journal of Dairy Science 85: 112-121.

Broadbent, J.R., Chou, Y.C., Gillies, K. and Kondo, J.K. (1989). Nisin inhibits several Gram-positive mastitis-causing pathogens. Journal of Dairy Science 72: 3342-3345.

Crispie, F., Flynn, J., Ross, R.P., Hill, C. and Meaney, W.J. (2004a). Dry cow therapy with a non-antibiotic intramammary teat seal - a review. Irish Veterinary Journal 57: 412-418.

Crispie, F., Twomey, D., Flynn, J., Ross, R. P., Hill, C. and Meaney, W.J. (2004b). The lantibiotic lacticin 3147 produced in a milk-based medium improved the efficacy of a bismuth-based teat seal in cattle deliberately infected with Staphylococcus aureus. Journal of Dairy Research (in press).

Fitzgerald, J.R., Meaney, W.J., Hartigan, P.J., Smyth, C.J. and Kapur, V. (1997). Fine-structure molecular epidemiological analysis of Staphylococcus aureus recovered from cows. Epidemiology and Infection 119: 261-269.

Huxley, J.N., Green, M.J., Green, L.E. and Bradley, A.J. (2002). Evaluation of the efficacy of an internal teat sealer during the dry period. Journal of Dairy Science 85: 551-561.

Martin, N.L., Sprules, T., Carpenter, M.R., Cotter, P.D., Hill, C., Ross, R.P. and Vederas, J.C. (2004). Structural characterisation of lacticin 3147, a two-peptide lantibiotic with synergistic activity. Biochemistry 43: 3049-3056.
McAuliffe, O., Ryan, M., Ross, R.P., Hill, C., Breeuwer, P. and Abee, T. (1998). Lacticin 3147, a broad-spectrum bacteriocin which selectively dissipates the membrane potential. Applied and Environmental Microbiology 64: 439-445.

McAuliffe, O., Hill, C. and Ross, R.P. (2000). Identification and overexpression of $\operatorname{LtnI}$, a novel gene which confers immunity to the two-component lantibiotic lacticin 3147. Microbiology 146: 129138.

Morgan, S.M., Galvin, M., Kelly, J., Ross, R.P. and Hill, C. (1999). Development of a lacticin 3147-enriched whey powder with inhibitory activity against foodborne pathogens. Journal of Food Protection 62: 1011-1016.

Pyörälä, S. (2002). New strategies to prevent mastitis. Reproduction in Domestic Animals 37: 211-216.

Rea, M.C. and Cogan, T.M. (1994). Buttermilk plants: the Irish version of kefir. The Irish Scientist 2: 7 .

Rogers, L.A. and Whittier, E.O. (1928). Limiting factors in lactic fermentation. Journal of Bacteriology 16: 211-214.

Ryan, M., Meaney, W.J., Ross, R.P. and Hill, C. (1998). Evaluation of lacticin 3147 and a teat seal containing this bacteriocin for inhibition of mastitis pathogens. Applied and Environmental Microbiology 64: 2287-2290.

Ryan, M.P., Flynn, J., Hill, C., Ross, R.P. and Meaney, W. J. (1999). The natural food grade inhibitor, lacticin 3147, reduced the incidence of mastitis after experimental challenge with Streptococcus dysgalactiae in nonlactating dairy cows. Journal of Dairy Science 82: 2625-2631.

Sears, P.M., Smith, B.S., Stewart, W.K., Gonzalez, R.N., Rubino, S.D., Gusik, S.A., Kulisek, E.S., Projan, S.J. and Blackburn, P. (1992a). Evaluation of a nisin-based germicidal formulation on teat skin of live cows. Journal of Dairy Science 75: 3185-3190.

Sears, P.M., Wilson, D.J. and Gonzalez, R.N. (1992b). The potential role of antimicrobial proteins in the treatment of bovine mastitis. In: Proceedings of the XVII World Buiatrics Congress, St. Paul, Minnesota. pp 138-142. Edited by E.I. Williams. Stillwater: American Association of Bovine Practitioners.

Taylor, J.I., Hirsch, A. and Mattick, A.T.R. (1949). The treatment of bovine streptococcal and staphylococcal mastitis with nisin. Veterinary Record 61: 197-198.

Twomey, D.P., Wheelock, A.I., Flynn, J., Meaney, W.J., Hill, C. and Ross, R.P. (2000). Protection against Staphylococcus aureus mastitis in dairy cows using a bismuth-based teat seal containing the bacteriocin, lacticin 3147. Journal of Dairy Science 83: 1981-1988.

Wellenberg, G.J., van der Poel, W.H.M. and Van Oirschot, J.T. (2002). Viral infections and bovine mastitis: a review. Veterinary Microbiology 88: 27-45.

Williamson, J.H., Woolford, M.W. and Day, A.M. (1995). The prophylactic effect of a dry cow antibiotic against Streptococcus uberis. New Zealand Veterinary Journal 43: 228-234.

Woolford, M.W., Williamson, A.M. and Copeman, P.A.J. (1998). The prophylactic effect of a teat sealer on mastitis during the dry period and the following lactation. New Zealand Veterinary Journal 46: 12-19 